\title{
IMPLEMENTASI KARAKTERISTIK GAYA BELAJAR (4 MAT SYSTEM) PESERTA DIDIK PRODI PENDIDIKAN AGAMA KRISTEN DI STT KRISTUS ALFA OMEGA, SEMARANG TAHUN AJARAN 2017/2018
}

\author{
Eni Rombe \\ (Dosen Prodi Pendidikan Agama Kristen: eni_rombe@yahoo.com)
}

\begin{abstract}
Learning style learning style is the best way used by students in learning to receive, absorb and process information received. This study aims to describe the characteristics of student learning styles which consist of the characteristics of the learning style of 4MAT System. The 4MAT System learning style developed by Bernice McCarthy proclaims four learning models namely; analytic learning, imaginative learning, common sense learning and dynamic learning. This study uses quantitative research methods with a type of descriptive research. With the research subject were students of the Christian Education Study Program at STT Kristus Alfa Omega, Semarang, which numbered 41 people. The technique of collecting data is done through questionnaires or questionnaires. The results showed the level of implementation of the 4MAT System learning style by the Christian Religious Education Study Program at the STT Kristus Alfa Omega, Semarang in the 2017/2018 academic year with a value of 77,177\% which was at a high percentage, between (61-80).
\end{abstract}

\section{A. PENDAHULUAN}

Setiap individu memiliki karakteristik gaya belajar yang berbeda. Beberapa peserta didik perlu melihat dahulu gambaran secara keseluruhan sebelum memecah-mecah suatu konsep menjadi bagian-bagian kecil, dan beberapa dapat belajar dengan sebaik-baiknya dalam langkah yang logis dan menginginkan aturan-aturan untuk mengerjakan tugas-tugas baru. Beberapa orang belajar paling baik di sebuah ruang yang tenang, yang lain membutuhkan latar belakang yang ramai. ${ }^{1}$ Gaya belajar yang berbeda pada setiap individu dipengaruhi oleh berbagai faktor, sebagaimana kutipan berikut:

"Berbagai penelitian telah dilakukan untuk membuktikan bahwa, ternyata kita memiliki cara belajar dan berpikir yang berbeda-beda. Mungkin anda akan merasa lebih efektif dan lebih baik dengan menggunakan lebih banyak mendengarkan, tetapi orang lain merasa lebih baik dengan membaca dan bahkan ada yang merasa bahwa hasilnya akan optimal jika belajar langsung mempraktikkan apa yang akan dipelajari. Bagaimana cara kita belajar akan sangat mempengaruhi struktur otak kita. Hal inilah yang kemudian kita kenal sebagai gaya belajar (learning style)".

Karakteristik gaya belajar menunjuk pada cara seseorang dalam berpikir, melalui mendengar, membaca, atau mempraktikkan apa yang dipelajari. Gaya belajar merupakan tindakan yang selalu digunakan seseorang dalam belajar. Menurut Keefa yang di kutip oleh Sugiarto dkk, menjelaskan bahwa, "gaya belajar berhubungan dengan cara anak belajar, serta cara yang disukai". ${ }^{3}$

\footnotetext{
${ }^{1}$ Marshall Carol dan Kaye Jhons, Suscces Strategies for At-Risk Students: Center for Succes in Learning Manual (Dallas, Center for Success in Learning, 1992), 16.

${ }^{2}$ https://www.trendilmu.com/2015/04/tipe-gaya-belajar.html, (diakses 16 Mei 2018, pukul 13.23 WIB).

${ }^{3}$ Sugihartono, dkk. Psikologi Pendidikan (Yogyakarta: UNY Press, 2007), 53.
} 
Gaya belajar berhubungan dengan cara seseorang dalam mempelajari sesuatu dan cara ini adalah cara yang disukai atau menimbulkan kesenangan. Cara belajar mencakup bagaimana seseorang dapat menerima, memahami dan mengingat informasi dengan sebaik-baiknya. ${ }^{4}$

Pendapat Gregorc dalam buku Susan B. Bastable, Perawat Sebagai Pendidik Menyatakan bahwa gaya belajar mengandung perilaku yang sifatnya berlainan dan dapat diobservasi, sehingga memberikan petunjuk tentang kemampuan mediasi setiap orang. Dia menyatakan bahwa pikiran manusia mempunyai saluran-saluran yang dapat menerima dan mengungkapkan informasi dalam cara yang efisien dan efektif. ${ }^{5}$

Berdasarkan pendapat beberapa ahli diatas, maka gaya belajar dapat diartikan sebagai cara yang lebih cenderung digunakan oleh peserta didik dalam belajar. Gaya belajar juga dapat diartikan sebagai cara yang digunakan peserta didik dalam menerapkan dan mengolah informasi yang diterima. DePorter dan Hernack berpendapat bahwa, gaya belajar adalah "kombinasi dari bagaimana individu menyerap dan kemudian mengatur, serta mengolah informasi". 6 Gaya belajar dapat diartikan sebagai cara seseorang belajar, yang mencakup cara menerima, memahami dan mengingat informasi dengan sebaik-baiknya. ${ }^{7}$ Sedangkan Uno berpendapat bahwa, "gaya belajar menunjukkan cara tercepat dan terbaik bagi individu untuk menyerap informasi dari luar dirinya". Gaya belajar berkaitan dengan cara seseorang dalam memahami, artinya mengerti dengan benar materi ajar yang dipelajari, mengingat informasi atau membangkitkan kembali dalam ingatan.

Menurut para ahli di National Learning Laboratory, the Center of Study of Learning and Teaching Styles di Universitas Saints Jhon, New York memaparkan bahwa, ada banyak faktor yang membentuk cara belajar seseorang dan mempengaruhi cara menerima, menyimpan dan menggunakan informasi. ${ }^{9}$ Ada orang yang dapat belajar dengan baik kalau dia sendiri, dalam sebuah kelompok belajar bersama teman-teman atau berada dalam ruangan kelas yang sangat terstruktur. Beberapa orang lebih mudah belajar ketika sudah melihat gambaran secara keselurahan dan materi yang akan dipelajari.

Beberapa orang lebih mudah belajar ketika berada di ruangan yang tenang, namun ada juga yang senang belajar di tengah keramaian. Mengenal gaya belajar setiap orang akan memudahkan untuk orang tersebut belajar, seperti yang disampaikan oleh DePorter bahwa:

"Memang benar, sebuah gaya belajar tak dapat menggambarkan dirimu sebagai individu secara keseluruhan. Tetapi jika kamu tahu cara belajar yang disukai otakmu, kamu akan bisa memakai pengetahuan ini untuk mengatur informasi agar pas dengan otakmu. Ini berarti, kamu akan lebih cepat "memahami" informasi dengan memasukkannya ke dalam gaya yang disukai otakmu". ${ }^{10}$

Dengan memahami gaya belajar yang sesuai dengan cara kerja otaknya, maka peserta didik akan lebih cepat dan lebih mudah untuk menerima dan mengolah informasi yang diterimanya, termasuk informasi mengenai materi pelajaran yang sedang dipelajari. Hal serupa juga disampaikan oleh Fuller yang menyatakan bahwa:

\footnotetext{
${ }^{4}$ Cheri Fuller, Maksimalkan Potensi Belajar Anak: Bagaimana Melengkapi Anak Agar Sukses di Sekolah dan dalam Kehidupan (Bandung: Kalam Hidup, 2007), 14.

${ }^{5}$ Susan B. Bastable, Perawat Sebagai Pendidik (t.k: EGC, 1995), 86.

${ }^{6}$ Bobbi DePorter dan Mike Hernack, Quantum Learning Membiasakan Belajar Nyaman dan Menyenangkan (Bandung: Kaifa, 2007), 112.

${ }^{7}$ Cheri Fuller, Maksimalkan Potensi Belajar Anak... 14.

${ }^{8}$ Hamzah B. Uno, Orientasi dalam Psikologi Pembelajaran (Jakarta: PT Bumi Aksara, 2010),

180.

${ }^{9}$ Cheri Fuller, 15 .

${ }^{10}$ Bobbi DePorter dan Mike Hernack, Quantum Learning Membiasakan Belajar ..., 112.
} 
Seseorang yang memahami gaya belajarnya akan memakai pengetahuan yang dimiliki untuk mengatur informasi agar sesuai dengan kemampuannya, sehingga lebih cepat memahami informasi. Semakin seseorang dapat memahami dirinya dan cara belajarnya, maka pendidik dapat memahami dan menolongnya. ${ }^{11}$

Seseorang perlu memahami dirinya, caranya memperoleh informasi, mengolah informasi, dan menarik kesimpulan informasi yang diterimanya serta menerapkan apa yang diajarkan.

Dengan mengetahui gaya pembelajaran yang disertai dengan pemilihan metode yang tepat, maka proses pembelajaran akan lebih fokus. Selain itu, juga diperlukan beberapa stimulus pada setiap gaya pembelajaran guna meningkatkan kualitas hasil pembelajaran. Selanjutnya, jika seseorang telah akrab dengan gaya belajarnya sendiri, maka dia dapat membantu dirinya sendiri dalam belajar lebih cepat dan lebih mudah. ${ }^{12}$

Peserta didik yang memahami gaya belajarnya dan menggunakan gaya belajar tersebut dalam menerima, menyerap dan mengolah setiap materi pelajaran, maka kegiatan proses belajar akan berlangsung dengan cepat dan maksimal. Gaya belajar merupakan pilihan seseorang dalam menerima dan memproses informasi yang diperolehnya. Gaya belajar yang memaksimalkan kerja otak kanan dan otak kiri memiliki kecenderungan dapat memproses informasi secara cepat. Semakin seseorang dapat memahami dirinya dan cara belajarnya, maka pendidik dapat memahami dan menolongnya. ${ }^{13}$ Dengan mengetahui gaya pembelajaran yang disertai dengan pemilihan metode yang tepat, maka proses pembelajaran akan lebih fokus. Selain itu, juga diperlukan beberapa stimulus pada setiap gaya pembelajaran guna meningkatkan kualitas hasil pembelajaran. Selanjutnya, jika seseorang telah akrab dengan gaya belajarnya sendiri, maka dia dapat membantu dirinya sendiri dalam belajar lebih cepat dan lebih mudah. ${ }^{14}$

Ditinjau dari keberagaman gaya belajar serta pentingnya mendorong peserta didik belajar sesuai dengan gaya atau karakteristik yang dimilikinya supaya proses pembelajaran, yaitu menerima, mengolah, menyimpan dan menggunakan informasi mengenai materi yang dipelajari dapat berlangsung secara cepat dan mudah, maka peniliti dalam penelitian ini memaparkan salah satu ragam gaya belajar dari berbagai jenis gaya belajar peserta didik yang ada. Gaya belajar yang peneliti paparkan adalah 4 gaya belajar. Empat gaya belajar ini dalam dalam dunia pendidikan dikenal dengan istilah 4MAT System. Gaya Belajar 4MAT System merupakan gaya belajar yang dikembangkan oleh Bernice McCarthy pada awal tahun 1980.

Deskripsi gaya belajar Bernice McCarthy dikenal dengan 4MAT System. Model 4MAT System dikembangkan pada awal 1980-an dan didasarkan pada dominasi otak kanan dan otak kiri, yang memberikan wawasan mengenai cara manusia pertama kali menerima dan kemudian memproses informasi. ${ }^{15}$

Kutipan ini menjelaskan bahwa, gaya belajar yang dikembangkan oleh Bernice McCarthy didasarkan pada dominasi atau cara kerja otak kanan dan otak kiri dalam menerima dan memproses informasi atau materi pelajaran yang telah diterima oleh peserta didik.

\footnotetext{
${ }^{11}$ Cheri Fuller, Maksimalkan Potensi Belajar Anak: Bagaimana Melengkapi Anak ..., 71.

${ }^{12}$ Bobby DePorter dan Mike Hernacki, Quantum Learning: Membiasakan Belajar . . ., 110112.

${ }^{13}$ Cheri Fuller, Maksimalkan Potensi Belajar Anak: Bagaimana Melengkapi Anak Agar Sukses di Sekolah dan dalam Kehidupan (Bandung: Kalam Hidup, 2007), 71.

${ }^{14}$ Bobby DePorter dan Mike Hernacki, Quantum Learning: Membiasakan Belajar Nyaman dan Menyenangkan. . ., 110-112.

${ }^{15}$ Barbara Prashnig, The Power of Learning Styles: Mendongkrak Anak Melejitkan Prestasi dengan Mengenali Gaya Belajarnya (Bandung: kaifa, 2007), 44.
} 
Lebih lanjut Bernice McCarthy menjelaskan bahwa pembelajar membentuk makna melalui sebuah putaran alami, yaitu bergerak dari merasakan ke merefleksikan, berpikir, dan melakukan. Empat gaya belajar tersebut adalah: 1) imajinative learner, 2) analytic learner, 3) common sense learner, 4) dynamic learner. ${ }^{16}$

Keempat gaya belajar, yaitu; imajinative learning, analytic learning, common sense learning, dan dynamic learning yang dicetuskan oleh Bernice McCarthy inilah yang menjadi fokus penelitian.

\section{B. METODOLOGI}

Metode penelitian yang digunakan dalam penelitian ini adalah kuantitatif dengan jenis penelitian deksriptif. Penelitian kuantitatif adalah penyelidikan dengan menggunakan ilmiah, yaitu prosedur langkah-langkah dalam memecahkan masalah atas dasar pengamatan empiris. ${ }^{17}$ Demikian juga yang dituliskan oleh Nasehudin mengenai pengertian metode penelitian kuantitatif yang menjelaskan bahwa: "metode penelitian kuantitatif adalah cara memperoleh ilmu pengetahuan atau memecahkan masalah yang dihadapi dan dilakukan secara hati-hati dan sistematis, dan data-data yang dikumpulkan berupa rangkaian atau kumpulan angka-angka" ${ }^{18}$ Penelitian deskriptif berkaitan dengan pengumpulan data untuk memberikan gambaran atau penegasan suatu konsep atau gejala, juga menjawab pertanyaan-pertanyaan sehubungan dengan status subyek penelitian pada saat ini, misalnya sikap atau pendapat terhadap individu, organisasi dan sebagainya. ${ }^{19}$ Penelitian deskriptif bertujuan untuk memaparkan, menggambarkan atau mendeskripsikan situasi yang terjadi pada populasi. Penelitian ini bertujuan untuk menggambarkan, mendeskripsikan atau memaparkan tentang Implementasi Gaya Belajar (4MAT System) oleh Peserta Didik Program Studi Pendidikan Agama Kristen di Sekolah Tinggi Teologi Kristus Alfa Omega Semarang.

\section{PEMBAHASAN}

\section{Pengertian Gaya Belajar}

Pemahaman gaya belajar dapat dipahami secara tepat jika terlebih dahulu memahami arti setiap kata yang terkait di dalamnya. Gaya belajar terdiri dari kata gaya dan belajar. Berdasarkan Kamus Besar Bahasa Indonesia, gaya dapat difenisikan tingkah laku, gerak gerik dan sikap. ${ }^{20}$ Sementara belajar dapat didefinisikan sebagai petunjuk yang diberikan kepada orang supaya diketahui, belajar adalah berusaha memeroleh kepandaian atau ilmu, dapat juga berarti berlatih dan atau berubah tingkah laku atau tanggapan yang disebabkan oleh pengalaman. ${ }^{21}$ Secara sederhana Anthony Robbins dalam bukunya Sagala, mendefinisikannya

\footnotetext{
${ }^{16}$ Bernice McCarthy.1990. "Using The 4mat System To Bring Learning Styles To Schools". www.ascd.org/ASCD/pdf/journals/.../el_199010_mccarthy.pdf; (diakses pada 23 Maret 2017).

${ }^{17}$ Andreas B. Subagyo, Pengantar Riset Kuantitatif \& Kualitatif (Bandung: Kalam Hidup, 2004), 54

${ }^{18}$ Toto Syatori Nasehudin dan Nanang Gozali, Metode Penelitian Kuantitatif (Bandung: CV. Pustaka Setia, 2012), 68.

${ }^{19}$ Sumanto. op.cit., 14.

${ }^{20}$ Tim Penyusun Kamus Pusat Pembinaan dan Pengembangan Bahasa, Kamus Besar Bahasa Indonesia (Jakarta: Gramedia Pustaka Utama, 2008), 422.

${ }^{21} \mathrm{http}$ //pusatbahasa.diknas.go.id/kbbi/Kamus Besar Bahasa Indoneis versi offline, Freeware C 2010 by Ebta Setiawan.
} 
sebagai proses menciptakan hubungan antara sesuatu (pengetahuan) yang sudah dipahami dan sesuatu (pengetahuan) yang baru. ${ }^{22}$ Definisi belajar menurut pendapat Anthony Robbins dapat dianggap bahwa, belajar itu bukanlah suatu proses yang berangkat dari ketidaktahuan sama sekali, tetapi belajar merupakan keterkaitan dari dua pengetahuan yang sudah ada dengan pengetahuan yang baru.

Belajar juga dapat diartikan sebagai proses atau langkah-langkah dalam mencapai suatu perubahan, seperti yang penjelasan George J. Mouly yang dikutip oleh Trianto dalam bukunya Psychology for Effective Teaching mengatakan bahwa: "belajar pada dasarnya adalah proses perubahan tingkah laku seseorang berkat adanya pengalaman". ${ }^{23}$ Pendapat yang senada dikemukakan oleh Kimble dan Garmezi yang mengatakan bahwa, belajar adalah perubahan". ${ }^{24}$ Jerome Brunner dalam Baharuddin mengemukakan bahwa:

Belajar adalah suatu proses aktif untuk membangun (mengkonstruk) pengetahuan baru berdasarkan pengalaman atau pengetahuan yang sudah dimilikinya, karenanya belajar bukan semata-mata mentransfer pengetahuan yang ada diluar dirinya, tetapi belajar lebih pada bagaimana otak memproses dan menginterpretasikan pengalaman yang baru dengan pengalaman yang sudah dimilikinya dalam format yang baru. ${ }^{25}$

Hal yang sederhana juga disampaikan oleh Makmun Khairani yang mendefinisikan belajar sebagai usaha atau kegiatan yang bertujuan mengadakan perubahan dalam diri seseorang, mencakup perubahan tingkah laku, sikap, kebiasaan, ilmu pengetahuan keterampilan dan sebagainya. ${ }^{26}$ Berdasarkan pendapat beberapa ahli di atas belajar dapat dipahami sebagai suatu proses aktif yang dilakukan untuk menuju perubahan yang bersifat permanen melalui proses latihan dalam interaksi dengan lingkungan.

Setelah memahami definisi kata "gaya" dan "belajar" yang telah dipaparkan di atas, maka selanjutnya peneliti akan memberikan penjelasan mengenai pengertian gaya belajar. Gaya belajar dapat diartikan sebagai cara yang digunakan oleh seorang peserta didik dalam menerima, memahami dan mengola informasi yang telah diterimanya, seperti pendapat Fuller, yang memaparkan definisi gaya belajar dapat sebagai cara seseorang belajar, yang mencakup cara menerima, memahami dan mengingat informasi dengan sebaik-baiknya. ${ }^{27}$ Lebih lanjut Uno berpendapat bahwa, "gaya belajar menunjukkan cara tercepat dan terbaik bagi individu untuk menyerap informasi dari luar dirinya". ${ }^{28}$ Gaya belajar adalah cara termudah dan nyaman untuk menyerap, mengatur dan mengolah informasi. ${ }^{29}$ Berdasarkan pendapat di atas dapat dipahami bahwa gaya belajar merupakan cara yang terbaik yang digunakan oleh peserta didik dalam menyerap informasi.

Gaya belajar juga dapat didefinisikan sebagai gabungan dari berbagai cara yang digunakan oleh peserta didik dalam belajar. Menurut DePorter dan Hernacki, gaya belajar

\footnotetext{
${ }^{22}$ Syaiful Sagala, Konsep dan Makna Pembelajaran untuk Membantu Memecahkan Problematika Belajar dan Mengajar, Cet. IX (Bandung, Alfabeta, 2011), 38.

${ }^{23}$ Trianto, Mendesain Model Pembelajaran Inovatif-Progresif: Konsep Landasan dan Implementasinya pada KTSP, Cet. IV (Surabaya: Kencana. 2011), 9.

${ }^{24}$ Trianto, 9.

${ }^{25}$ H. Baharuddin dan Esa Nur Wahyuni, Teori Belajar dan Pembelajaran, Cet.V (Jogjakarta, Ar- Ruzz Media: 2010), 115.

${ }^{26}$ Makmun Khairani, Psikologi Belajar (Yogyakarta: Aswaja Pressindo, 2013), 3-4.

${ }^{27}$ Cheri Fuller, Maksimalkan Potensi Belajar Anak: Bagaimana Melengkapi Anak Agar Sukses di Sekolah dan dalam Kehidupan (Bandung: Kalam Hidup, 2007), 14.

${ }^{28}$ Hamzah B. Uno, Orientasi dalam Psikologi Pembelajaran (Jakarta: PT Bumi Aksara, 2010), 180.

${ }^{29}$ Amir Faisal dan Zulfanah, Menyiapkan Anak Jadi Juara (Jakarta: PT Media Komputindo,
} 2008), 121. 
adalah kombinasi dari bagaimana individu menyerap dan kemudian mengatur, serta mengolah informasi. ${ }^{30}$ Sedangkan menurut James dan Garner dalam bukunya Gaya Belajar memberikan definisi untuk gaya belajar sebagai cara yang kompleks dimana para peserta didik menganggap dan merasa paling efektif dan efisien dalam memproses, menyimpan dan memanggil kembali apa yang mereka dipelajari. ${ }^{31}$

Gaya belajar merupakan karakteristik atau perilaku serta sifat yang dimiliki oleh seseorang dalam melakukan kegiatan belajar. Pendapat Gregorc dalam buku Susan B. Bastable, Perawat Sebagai Pendidik menjelaskan bahwa:

Gaya belajar mengandung perilaku yang sifatnya berlainan dan dapat diobservasi sehingga memberikan petunjuk tentang kemampuan mediasi setiap orang. Dia menyatakan bahwa pikiran manusia mempunyai saluran-saluran yang dapat menerima dan mengungkapkan informasi dalam cara yang efisien dan efektif. ${ }^{32}$

Gregorc yakin bahwa banyak orang yang memiliki kemampuan untuk bekerja sampai tingkat tertentu dalam semua gaya, meskipun $90 \%$ peserta didik mampu belajar lebih baik hanya dengan satu atau kemungkinan dua gaya belajar. Dalam situasi belajar yang baru atau penuh tekanan, peserta didik akan memperlihatkan karakteristik gaya tertentu yang lebih dominan. ${ }^{33}$ Berdasarkan cara yang digunakan peserta didik dalam menyelesaikan persoalan secara khusus mengenai proses pembelajaran dapat dilihat, dipahami karakteristik pribadinya.

Seluruh definisi gaya belajar di atas tampak tidak ada yang bertentangan, melainkan memiliki kemiripan antara yang satu dengan yang lainnya. Definisi-definisi gaya belajar tersebut secara subtansial tampak saling melengkapi. Berdasarkan keterangan-keterangan di atas maka penulis mengambil kesimpulan bahwa gaya belajar yaitu suatu cara pandangan pribadi terhadap peristiwa yang dilihat dan dialami. Oleh karena itulah pemahaman, pemikiran, dan pandangan seorang anak dengan anak yang lain dapat berbeda, walaupun kedua anak tersebut tumbuh pada kondisi dan lingkungan yang sama, serta mendapat perlakuan yang sama.

\section{Sejarah Munculnya Gaya Belajar $4 M A T$}

Gaya belajar yang dikenal dengan istilah Gaya Belajar 4MAT System adalah gaya belajar yang dikembangkan pada awal 1980-an dan didasarkan pada dominasi otak kanan dan kiri, yang memberikan wawasan mengenai cara manusia pertama kalai menerima dan kemudian memproses informasi. ${ }^{34}$ Seperti yang dijelaskan oleh Susan B. Bastable bahwa Gaya Belajar 4MAT System pertama kali diperkenalkan oleh McCarthy pada tahun 1980.

McCarthy mengembangkan sebuah model berdasarkan penelitian sebelumnya tentang gaya belajar dan cara kerja otak. Secara khusus dia menggunakan model Kolb yang dikombinasikan dengan temuan pada penelitian otak kanan-kiri untuk menciptakan $4 M A T$ System. ${ }^{35}$

Hal ini juga dijelaskan oleh Lorna Earl dan kawan-kawannya dalam buku Schooling for Change: Reinventing Edication for Early Adolescents bahwa:

\footnotetext{
${ }^{30}$ Bobbi DePorter dan Mike Hernack, Quantum Learning Membiasakan Belajar Nyaman dan Menyenangkan (Bandung: Kaifa, 2007), 112.

${ }^{31}$ Darmadi, Pengembangan Model dan Metode Pembelajaran dalam dinamika belajar siswa (Yogyakarta: Deepublish, 2017), 158.

${ }^{32}$ Susan B. Bastable, Perawat Sebagai Pendidik (t.k: EGC, 1995), 86.

${ }^{33}$ Ibid. 87.

${ }^{34}$ Barbara Prashing, The Power Learning Styles: Memacu Anak Melejitkan Prestasi dengan Menggali Gaya Belajarnya (Bandung: Kaifa, 2017), 44.

${ }^{35}$ Susan B. Bastable ...., 87.
} 
The 4 MAT system, developed by McCarthy (1980) is another approach to planning teaching and learning that is designed to ensure that students with very different ways of learning are taught and learn in ways that are compatible with their learning style. She has used a 4-quadrant model to construct a framework for planning teaching and learning that identifies students who are primary "innovative learners," "analytic learners', 'common sense learners' and dynamic learners. ${ }^{36}$

Berdasarkan kutipan di atas dapat dipahami bahwa sistem 4MAT, dikembangkan oleh McCarthy (1980) adalah pendekatan lain untuk perencanaan pengajaran dan pembelajaran yang dirancang untuk memastikan bahwa, peserta didik dengan cara belajar yang sangat berbeda diajarkan dan belajar dengan cara yang sesuai dengan gaya belajar mereka. Sistem $4 M A T$ menggunakan model kuadran yang terdiri atas 4 kuadran untuk membangun kerangka kerja untuk merencanakan pengajaran dan pembelajaran yang mengidentifikasi peserta didik yang merupakan 'pembelajar inovatif', 'pembelajar analitik', 'pembelajar akal sehat', dan 'pembelajar dinamis' Hal yang serupa juga disampaikan oleh Liliwer bahwa:

Pada tahun 1979, Benice McCarthy mengembangkan teori sistem belajar 4MAT bersumber Learning Styles Inventory and Experiential Learning Model dari Kolb. Mc.Carthy menemukan 4 tipe belajar, yaitu: tipe 1, divergers (pertanyaan favorit: why). Tipe 2, assimilators (pertanyaan favoritnya; what). Tipe 3, covergers (pertanyaan favorit; how), dan tipe 4 accomodators (pertanyaan favorit: what if). ${ }^{37}$ Bernice McCarthy mencanangkan empat model pembelajaran yaitu; analitis, imaginatif, akal waras atau common sense dan dinamik. ${ }^{38}$

Lorna Earl dan kawan-kawannya dalam buku "Schooling for Change: Reinventing Edication for Early Adolescents" juga menekankan tujuan dari penerapan Gaya Belajar 4MAT System yaitu:

This framework offers a wide range of activities that would be appropriate to each of them. Although she isolates theses categories and provides teaching strategies associated with them, she is quick to point out that the intent is not to pigeon-hole students or limit their access to learning but to extend it by using all strategies with the whole class and ensuring that all students benefit by experiencing a variety of teaching approaches. These are only a very few examples of what is available to teachers who to make learning meaningful and relevant bay extending and enriching the experiences of students experiences. ${ }^{39}$

Kerangka kerja ini menawarkan berbagai kegiatan yang sesuai untuk masing-masing. Meskipun mengisolasi kategori-kategori ini dan memberikan strategi pengajaran yang terkait dengan para peserta didik, dengan cepat menunjukkan bahwa tujuannya bukan untuk membuat peserta didik berlaku secara otomatis 'merpati-lubang' atau membatasi akses untuk belajar tetapi untuk memperluasnya dengan menggunakan semua strategi dengan seluruh kelas dan memastikan bahwa semua peserta didik mendapat manfaat dengan mengalami berbagai pendekatan pengajaran. Ini hanyalah sedikit contoh dari apa yang tersedia bagi para guru yang membuat pembelajaran yang bermakna dan relevan memperluas dan memperkaya pengalaman belajar peserta didik.

\footnotetext{
${ }^{36}$ Andy Hargreaves, Lorna Earl, dan Jim Ryan, Schooling for Change: Reinventing Edication for Early Adolescents (London: Falmer Press, 1996),

${ }^{37}$ Alo Liliwer, Komunikasi Serba Ada Serba Makna (Jakarta: Kencana media group, 2011), 326.

${ }^{38}$ Azizi Yahaya, Asmah Suboh, Zurihanmi Zakariya dan Fauziah Yahya, Aplikasi Kognitif dalam Pendidikan (Kuala Lumpur: Zafar SDn Bhd, 2005), 7.

${ }^{39}$ Andy Hargreaves, Lorna Earl, dan Jim Ryan, Schooling for Change:
} 
3. Indikator Gaya Belajar $4 M A T$

a) Imajinative Learning (Gaya Belajar Imajinatif)

Orang memiliki gaya belajar imajinatif. Imaginative learning adalah orang-orang yang menikmati tindakan sebagai bagian dari proses pembelajaran. Seperti yang dijelaskan oleh Buechner dalam buku yang berjudul The Son of Laugther bahwa: Dynamic Learners also enjoy action as part of the learning process. ${ }^{40}$ Karakteristik yang dimiliki oleh seorang peserta didik yang imaginative learning atau yang gaya belajar imajinatif adalah:

1) Menggunakan Kata Tanya "Mengapa?"

Sering menggunakan kata tanya "mengapa?" atau "why'. Seperti yang dijelaskan oleh Le Ferever dalam bukunya yang berjudul Learning Stayles: Reaching Everyone God Gave You To Teach menjelaskan bahwa: Question: What di I need to know? Pertanyaan: 'apa yang perlu saya ketahui hari ini? ${ }^{41}$ Tipe peserta didik ini sering menggunakan kata tanya, "mengapa ini penting? Mengapa saya harus mencoba mempelajari ini? ${ }^{42}$ Pembelajar imginative learning sering menggunakan kata tanya "mengapa?". Kata tanya "mengapa?" merupakan kata tanya yang digunakan untuk mencari suatu alasan atau penyebab.

\section{2) Menekankan pada Perasaan}

Gaya berpikir orang yang gaya belajarnya adalah imaginative learning segala sesuatu sering dihubungkan dengan perasaan dan emosi, sehingga mereka terkenal sangat sensitif. Bagi peserta didik yang gaya belajarnya adalah imaginative learning semua bisa menjadi menyenangkan jika mood-nya sesuai tetapi menjadi buruk jika mereka sudah tidak lagi memiliki emosi positif terhadap sessuatu. Mudah kehilangan konsentrasi, banyak pertimbangan, dan suka mencoret-coret tanpa arti dalam bukunya. ${ }^{43}$ Hal yang menonjol pada mereka adalah mereka sangat memahami akan perasaan dan emosi. ${ }^{44}$

\section{3) Senang Membangun Relasi}

Seorang peserta didik yang gaya belajarnya adalah imaginative learning akan sangat menjaga hubungan dengan orang lain, tidak senang jika mengalami konflik, dan dikenal "perhatian" di antara orang-orang sekitarnya. ${ }^{45}$ Beberapa hal yang dapat menunjukkan bahwa peserta didik yang gaya belajarnya adalah imaginative learning senang membangun relasi atau hubungan dengan orang lain, yaitu: 1). Senang mendengarkan orang lain. 2). Sangat memahami perasaan dan emosi orang lain. 3). Membawa kerukunan pada kelompok. 4). Berhubungan baik dengan orang lain. 5). Mengenali dan menghargai emosional orang lain. $^{46}$

4) Seseorang yang Sangat Kreatif

Seorang peserta didik yang gaya belajarnya adalah imaginative learning dapat digolongan dalam kelompok orang yang kreatif. Kreatif di sini dapat didefinisikan sebagai kemampuan untuk menciptakan. ${ }^{47}$ Ciri-ciri orang yang kreatif, yaitu:

${ }^{40}$ Frederik Buechner, The Son of Laugther (San Francisco: Hangger, 1993), 21.

${ }^{41}$ Marlene D. Le Ferever, Learning Stayles: Reaching Everyone God Gave You To Teach (Colorado Spring, Co 809 USA: David C. Cook, 2004), 25-26.

${ }^{42}$ Susan B. Bastable, 88 .

${ }^{43}$ Lilik Hidayat, Mutiara Belajar (), 28-29.

${ }^{44}$ Ibid. 29.

${ }^{45}$ Ibid. 29.

${ }^{46}$ Ibid. 29.

${ }^{47}$ Luvy Sofiah, Yudisthira dan R. Ardiansyah, Seri Panduan Belajar dan Evaluasi Ekonomi, 
- Memiliki rasa ingin tahu yang besar. Orang kreatif selalu ingin tahu apa yang terjadi di sekelilingnya. Rasa ingin tahu yang besar menjadi motivasi untuk melakukan sesuatu. ${ }^{48}$

- Menyukai tantangan. Peserta didik yang kreatif akan memandang masalah bukan sebagai suatu halangan tetapi akan selalu melihatnya sebagai suatu tantangan. Jika dapat diselesaikan maka akan ada kepuasan tersendiri. Orang kreatif selalu melihat permasalahan sebagai hal yang menarik dan mau menerima permasalahan tersebut. ${ }^{49}$

- Berpikir dari berbagai macam sudut pandang. Orang kreatif lebih dominan berpikir dengan otak kanan. Sehingga mampu melihat masalah dari berbagai sudut pandang dan mencari jalan keluarnya. ${ }^{50}$ Seperti yang disampaikan oleh Irham dan Wijani dalam bukunya Psikologi Pendidikan: Teori dan Aplikasi dalam Pembelajaran, bahwa:

"Otak kanan bekerja secara acak, memahami sesuatu secara global ke hal-hal yang detail, membaca dengan menyeluruh, lebih fokus pada bentuk gambar dan grafik, proses belajar diawali dengan melihat dulu atau mengalami kemudian terjadi proses belajar secara alamiah dan spontan". ${ }^{51}$

- Optimis. Rasa optimis membuat peserta didik berkeyakinan bahwa setiap masalah pasti ada solusinya dan tidak ada tantangan yang terlalu besar baginya. Ini bukan berarti orang kreatif selalu bahagia dan tidak pernah merasa tertekan atau depresi, tapi mereka tidak membiarkan dirinya tenggelam dan berdiam diri dalam menghadapi masalah. Pendapat Seligman yang dikutip oleh Robbins bahwa: "Optimis adalah reaksi terhadap kehidupan dari sudut pandang kekuatan diri". ${ }^{52}$

- Fleksibel. Orang kreatif menyelesaikan permasalahan dengan cara yang mungkin tidak pernah terpikirkan oleh kita. Cara mereka menyelesaikan masalah terlihat sangat sederhana, tidak berbelit-belit dan tidak rumit. Orang kreatif mempunyai pemikiran dan imajinasi yang fleksibel sehingga berbagia celah mudah terlihat. ${ }^{53}$

Selain dapat diamati melalui karakteristik yang dominan, gaya belajar seorang peserta didik juga dapat diamati melalui cara atau metode belajar yang digunakan. Berikut ini beberapa metode belajar yang digunakan atau disenangi oleh peserta didik yang gaya belajarnya adalah imaginative learning yaitu:

\section{1) Belajar melalui Interaksi Kelompok}

Peserta didik yang gaya belajarnya adalah imaginative learning akan sangat senang dan menikmati belajar melalui interaksi kelompok. Interaksi merupakan proses timbal balik, dimana suatu kelompok dipengaruhi tingkah reaktif pihak lain. ${ }^{54}$ Interaksi kelompok merupakan proses atau hubungan timbal balik yang terjadi dalam suatu kelompok.

Belajar melalui interak atau kerja kelompok adalah suatu cara belajar dengan cara menyeluruh. Seperti yang disampaikan oleh Edison bahwa: "metode kerja kelompok adalah suatu cara menyajikan bahan pelajaran dengan penyeluruh kepada peserta didik." ${ }^{\text {} 55}$ Kerja kelompok juga dapat memupuk dan menumbuhkan sikap kerja sama yang baik dalam

\footnotetext{
${ }^{48}$ Ibid. 67.

${ }^{49}$ Ibid. 67.

${ }^{50}$ Luvy Sofiah, Yudisthira dan R. Ardiansyah, ... 67.

${ }^{51}$ M. Irham dan Novan Ardy Wijani, Psikologi Pendidikan: Teori dan Aplikasi dalam Pembelajaran (Yogyakarta: Ar_Ruzz Media, 2013), 44.

${ }^{52}$ Mike Robbins, Focus on the Good Stuff: Mukjizat Bersyukur dan Bermental Positif (Jakarta: PT. Serambi Ilmu, 2007), 104.

${ }^{53}$ Luvy Sofiah, Yudisthira dan R. Ardiansyah, ... 67.

${ }^{54}$ Tim Mitra Guru, Sosiologi: Ilmu Pengetahuan Sosial (t.k: Erlangga, 2006), 36.

${ }^{55}$ Thomas Edison, 46.
} 
kelompok. Seperti yang disampaikan oleh Edison, salah satu keunggulan metode kerja kelompok adalah melatih peserta didik untuk bekerja sama, mengendalikan diri, dan dapat mempererat hubungan antarpeserta didik. ${ }^{56}$ Berdasarkan pendapat di atas dapat dipahami bahwa, melalui interaksi atau kerja kelompok peserta didik dapat belajar secara menyeluruh dan juga dapat membangun, menumbuhkan, dan melatih sikap kerja sama yang baik antar peserta didik.

\section{2) Belajar melalui Mendengarkan}

Orang yang senang belajar melalui cara mendengar disebut dengan istilah 'auditory'. Orang yang belajar melalui pendengaran (auditory), belajar dengan mengandalkan pendengarannya untuk bisa memahami sekaligus mengingatnya. Karakteristik model belajar ini benar-benar menempatkan pendengaran sebagai alat utama untuk menyerap informasi atau pengetahuan. Artinya untuk bisa mengingat dan memahami informasi tertentu, yang bersangkutan haruslah mendengar lebih dulu. ${ }^{57}$ Salah satu alat yang paling berperan ketika peserta didik belajar melalui mendengarkan adalah indra pendengaran. Jika pendengarannya baik maka informasi yang diterima juga akan maksimal.

Peserta didik yang senang belajar melalui mendengarkan akan lebih mudah mencerna, mengolah, dan menyampaikan informasi dengan cara mendengarkan secara langsung. Kecenderungannya belajar atau menerima informasi dengan mendengarkan atau secara lisan. Namun kesulitan yang dialami oleh peserta didik ini adalah akan mengalami kesulitan dalam menyerap informasi dalam bentuk tulisan, selain itu juga memiliki kesulitan dalam menulis atau membaca. ${ }^{58}$ Berdasarkan pendapat di atas maka dapat dipahami bahwa, peserta didik yang belajar melalui pendengarannya akan sangat mudah menerima dan memproses informasi atau materi yang diterima melalui pendengaran, tetapi akan mengalami kesulitan dalam menerima atau mengolah informasi atau materi pelajaran yang diterima secara tertulis.

\section{3) Belajar melalui Bercerita}

Bercerita adalah suatu kegiatan yang dilakukan seseorang secara lisan kepada orang lain dengan alat tentang apa yang harus disampaikan dalam bentuk pesan, informasi yang dikemas dalam bentuk cerita yang dapat didengarkan dengan rasa menyenangkan. Hal yang sama juga disampaikan oleh Hasmawati bahwa, bercerita adalah menuturkan sesuatu yang mengisahkan tentang perbuatan atau suatu kejadian dan disampaikan secara lisan dengan tujuan membagikan pengalaman dan pengetahuan kepada orang lain. ${ }^{59}$

Belajar melalui cara bercerita merupakan cara belajar yang akan mendorong peserta didik untuk bersifat produktif. Artinya, dalam bercerita seseorang melibatkan pikiran, kesiapan mental, keberanian, perkataan yang jelas, sehingga dapat dipahami oleh orang lain. ${ }^{60}$ Saat belajar melalui cara bercerita melibatkan seluruh aspek kehidupan peserta didik. Seperti yang disampaikan oleh al_Tabany bahwa "Bercerita dapat mengembangkan imajinasi, daya pikir dan penguasaan bahasa anak" ${ }^{61}$ Pendapat ini juga didukung oleh penjelasan Bachtiar S. Bachri yang dikutip oleh Hasmawati dalam jurnal Indragiri, Volume 1

\footnotetext{
${ }^{56}$ Thomas Edison, 46.

${ }^{57}$ Lilik Hidayat, 23.

${ }^{58}$ Ibid., 23.

${ }^{59}$ Journal Indragiri, Volume 1 (Indonesia: PT. Indragiri Dot Com Indonesia, 2017), 10.

${ }^{60}$ Ibay Toyyibah, Cara Belajar Gue Bangeeettt: Cara-cara Velajar menurut Kecerdasan dan Potensi Genetik (Jakarta: Eles Media Komputindo, 2017), 154.

${ }^{61}$ Trianto Ibnu Badar al_Tabany, Desain Pengembangan Pembelajaran Tematik (Jakarta: Kencana, 2013), 94.
} 
menyatakan bahwa: "melalui bercerita peserta didik dapat mengembangkan beberapa keterampilan sebagai berikut: 1). Keterampilan mendengarkan. 2). Keterampilan berbicara. 3). Keterampilan berasosiasi. 4). Keterampilan berekspresi dan berimajinasi 4) keterampilan berpikir atau logika. ${ }^{62}$ Bercerita dapat menumbuhkan, meningkatkan dan mengembangkan kemampuan yang dimiliki oleh setiap peserta didik dalam segala aspek.

\section{b) Analytic Learning (Gaya Belajar Analitik)}

Orang yang berpikir analitik dalam memandang segala sesuatu cenderung lebih terperinci, spesifik, terorganisasi, dan teratur. Namun kurang bisa memahami masalah secara menyeluruh. Seperti yang disampaikan oleh Hidayat bahwa:

Saat mengerjakan tugas, seorang analitik akan mengerjakannya secara teratur, dari satu tahap ke tahap berikutnya. Mereka memiliki lebih kecenderungan untuk mengerjakan satu tugas dalam satu waktu, dan belum akan mengerjakan yang lain sebelum tugas pertamanya selesai. Orang analitik membutuhkan waktu yang cukup untuk menyelesaikan tugasnya, karena mereka tidak ingin ada satu bagian yang terlewat. Orang yang memiliki cara berpikir secara analitik seringkali memikirkan sesuatu berdasarkan logika. ${ }^{63}$

Berdasarkan kutipan di atas dapat dipahami bahwa peserta didik yang memiliki gaya belajar analytic learning adalah orang yang mengerjakan tugas secara rinci dari tahap ke tahap dan tidak dapat mengerjakan banyak hal dalam waktu yang bersamaan. Lebih lanjut dijelaskan oleh Mitra menyatakan bahwa:

Analytic learners examine information by breaking it down into segments. They also arrange it in a logical manner. They like order and sequence. They make lists to organize details. If your child is an analytic learner, he is happier when things move forward in a predicable manner. He knows what the rules are and right away understands what is expected of him. He also follows a prescribed plan. Analytical learners are able to see the end result or the goal clearly. This helps keep them focused and productive. ${ }^{64}$

Pelajar analitik memeriksa informasi dengan memecahnya menjadi beberapa segmen atau tahap. Mereka juga mengaturnya dengan cara yang logis. Mereka suka pesanan dan urutan. Mereka membuat daftar untuk mengatur detail. Jika anak Anda adalah seorang pembelajar analitik, ia lebih bahagia ketika hal-hal bergerak maju dalam cara yang dapat diprediksi. Dia tahu apa aturannya dan segera memahami apa yang diharapkan darinya. Dia juga mengikuti rencana yang ditentukan. Pembelajar analitis dapat melihat hasil akhir atau tujuan dengan jelas. Ini membantu mereka tetap fokus dan produktif. Hal yang sama juga disampaikan oleh Dunn and Griggs bahwa: Analytics learn best in a quiet, brightly lighted and formal learning environment. They usually do not snack while working; they like to work alone, prefer to start and finish one project at a time. ${ }^{65}$ Peserta didik yang gaya belajarnya analytic learning paling baik dalam lingkungan belajar yang tenang, terang, dan formal. Mereka biasanya tidak ngemil saat bekerja; mereka suka bekerja sendiri, lebih suka memulai dan menyelesaikan satu proyek dalam satu waktu.

\footnotetext{
${ }^{62}$ Journal Indragiri, Volume 1 (Indonesia: PT. Indragiri Dot Com Indonesia, 2017), 10-11.

${ }^{63}$ Lilik Hidayat, Mutiara Belajar (), 31.

${ }^{64}$ Laxmi Mitra. Discipline Your Child: A Guide to Raising Respnsible and Independent Children (USA: Xlibris, 2012), 124.

${ }^{65}$ Rita Dunn and Shirley A. Griggs. Practical Approaches to Using Learning Styles in Higher Education. Westport (Connecticut London: Bergin \& Garvey, 2000), 203-204.
} 
Beberapa karakteristik peserta didik yang memiliki gaya belajar analytic learning adalah sebagai berikut:

\section{1) Menggunakan Kata Tanya “Apa?"}

Peserta didik yang memiliki gaya belajar analytic learning sering menggunakan kata tanya "apa?" atau "what" seperti yang dijelaskan oleh Le Ferever bahwa: 'Question: What di I need to know? Pertanyaan: 'apa yang perlu saya ketahui hari ini? ${ }^{66}$ Tipe ini pembelajaran dimulai dari otak kanan untuk mengobservasi dan mengintegrasi pengetahuan yang ada. Peserta didik kemudian memakai otak kiri untuk berpikir tentang teori dan konsep baru yang berhubungan dengan observasi ini. Mereka bertanya, "apa kiranya yang harus dipelajari? Apa hubungannya?"67 seperti yang dijelaskan oleh Liliwer bahwa: "pertanyaan favorit mereka adalah what? yang berkembang menjadi what are the facts (apa saja faktor-faktor yang ditampilkan)." Kata tanya "apa" digunaka untuk menanyakan benda atau sesuatu, keadaan atau perbuatan, dan segala sesuatu yang berkaitan dengan isi atau pokok bahasan.

\section{2) Menekankan pada Intelektual}

Peserta didik yang gaya belajar analytic learning adalah orang senang terhadap halhal yang berkaitan dengan intelektual. Kemampuan yang terlihat aritmatika, membaca dan menulis. Seperti yang disampaikan oleh Sonner bahwa:

"For this reason, these individuals are usually quite good at reading, writing and mathematics in school. These subject, as taught in most schools, require students to associate individual letters with individual letters with individual sounds, to memorize sets of rules, and to use abstract logic",69

Untuk alasan ini, orang-orang ini biasanya cukup pandai membaca, menulis dan matematika di sekolah. Mata pelajaran ini, seperti yang diajarkan di sebagian besar sekolah, mengharuskan siswa untuk mengaitkan huruf-huruf individu dengan huruf-huruf individual dengan suara-suara individual, untuk menghafal seperangkat aturan, dan menggunakan logika abstrak.

Bahkan lebih lanjut Liliwer menguraikan ciri-ciri peserta didik yang gaya belajarnya analytic learning sebagai berikut:

a. Kuat dalam logika dan tertib belajar

b. Mencari dan menemukan dari informasi yang akurat melalui pendapat para pakar.

c. Fokus pada konsep dan ide

d. Dapat bekerjasama dalam kelompok, manum mereka lebih suka bekerja sendirian, cenderung berorientasi pada detail informasi, artinya mereka sangat berhati-hati dengan detail informasi yang mereka peroleh.

e. Gaya belajar mereka dengan membaca, mengamati, mengumpulkan data, dan menganalisis.

f. Belajar membentuk teori dan menghargai prosedur pemerolehan pengetahuan.

g. Unggul dalam mengintegrasikan pengetahuan, perencanaan dan menciptakan teori.

h. Lebih suka instruktur/pemimpin mengajar kuliah tradisional.

i. Kadang-kadang tampilan mereka tidak praktis karena terlalu teoritis. ${ }^{70}$

\footnotetext{
${ }^{66}$ Marlene D. Le Ferever, Learning Stayles: Reaching Everyone God Gave You To Teach (Colorado Spring, Co 809 USA: David C. Cook, 2004), 25-26.

${ }^{67}$ Susan B. Bastable, 88 .

${ }^{68}$ Allo Liliwer, 327-328.

${ }^{69}$ Isadore L. Sonner. Affective Education: Methods and Teachniques (Engewood Cliffs: Educational Technology Publications. 1989), 198.

${ }^{70}$ Allo Liliwer, 327-328.
} 
3) Senang Berkompetisi

Kata kompetensi itu sendiri memang berasal dari bahasa asing, yang kini sudah dipakai dalam kosa kata Bahasa Indonesia sehari-hari. Kamus Besar Bahasa Indonesia memberikan batasan pengertian kompetensi, yaitu satu kata yang mengandung dua makna pokok, yaitu persaingan dan pertandingan. ${ }^{71}$ Kompetisi adalah persaingan secara sehat baik inter maupun antarpribadi. Kompetisi interpribadi adalah kompetisi dalam diri pribadi masing-masing dari tindakan atau unjuk kerja dalam dimensi tempat dan waktu. Dengan persaingan secara sehat dapat ditimbulkan motivasi untuk bertindak secara lebih baik. ${ }^{72}$ Kompetisi adalah usaha untuk melakukan sesuatu secara lebih baik dibanding orang lain. seperti yang disampaikan oleh Setyono bahwa:

"Kompetisi merupakan persaingan yang ditandai dengan adanya perlombaan atau persaingan untuk mengejar nilai tertentu, serta saling mengatasi dan berjuang antara dua individu atau antar kelompok untuk memperebutkan objek yang sama dengan cara sportif, atau tidak ada upaya saling menghalangi atau menjatuhkan satu dan lainnya."73

Melalui sikap kompetisi peserta didik dapat membangun beberapa hal yang bersifat positif yaitu:

a. Mendorong kemauan dan motivasi. Kompetisi sangat erat dengan dorongan kemauan atau motivasi. Semangat berjuang dan motivasi dapat ditumbuhkembangkan melalui wadah kompetisi. Dasar utama mengikuti persaingan adalah kemauan yang kuat. Tidak ada atau tidak akan terjadi kompetisi tanpa dilandasi dengan dorongan atau motivasi yang kuat. ${ }^{74}$ Hal yang sama disampaikan Raharjo bahwa: "kompetisi akan membawa semangat dan hasrat yang tak terdefinisikan. Bagaimanapun, meski Anda memiliki kemampuan pas-pasan, namun saat aura kompetisi itu hinggap di pikiran Anda, maka Anda akan mengeluarkan kemampuan Anda. Kompetisi selalu membuat Anda mampu menemukan warna baru dalam sebuah proses." ${ }^{75}$ Sikap dan tindakan kompetisi yang sehat dan sportif memberikan semangat dan motivasi agar dapat berbuat dan meraih sesuatu lebih baik dari orang lain.

b. Kompetisi dapat mengembangkan kepribadian, yaitu: 1). Melatih keberanian peserta didik. 2). Melatih rasa percaya diri peserta didik. 3). Semakin memahami kemampuan peserta $\operatorname{didik}^{76}$

Berikut ini beberapa metode belajar yang digunakan atau disenangi oleh peserta didik yang gaya belajarnya adalah analitytic learning yaitu:

1) Belajar melalui Ceramah

Metode ceramah merupakan metode yang digunakan paling awal karena sejak dimulainya pendidikan metode ini sudah digunakan. Metode ceramah digunakan untuk

\footnotetext{
${ }^{71}$ Hardywinoto \& Tony Setiabudhi, Anak Unggul Berontak Prima (Jakarta: Gramesia Pustaka Utama, 2002), 200. 2007), 142.

${ }^{72}$ Tim Pengembang Ilmu Pendidikan, Ilmu \& Aplikasi Pendidikan (t.k.: Imperial Bhakti Utama, 2011), 421.

${ }^{73}$ Budhi Setyono, Bahas Total: Kumpulan Soal \% Pembahasan (Yogyakarta: Indonesia Tera,

${ }^{74}$ Hardywinoto \& Tony Setiabudhi, Anak Unggul .... 202.

${ }^{75}$ E. Raharjo, Change! From Now: Rahasia Melejitkan Potensi Diri dan Menguasai Seni Berkomunikasi (Yogyakarta: Jogja Bangkit Publisher, 2010), 135.

${ }^{76}$ Meta Hanindita, Play and Learn (Yogyakarta: Stiletto Book, 2015), 128.
} 
menyampaikan informasi dan pengetahuan secara lisan kepada peserta didik. ${ }^{77}$ Setidaknya ada dua alasan seorang peserta didik memilih metode ceramah, yaitu1) ketika pendidik menyampaikan materi pelajaran baru, 2) saat pendidik berusaha untuk menghubungkan materi yang sudah dipelajari dengan materi yang baru diajarkan. ${ }^{78}$

\section{2) Belajar melalui Demonstrasi}

Metode demonstrasi merupakan metode mengajar yang menyajikan bahan pelajaran dengan mempertujukkan secara langsung objeknya atau caranya melakukan sesutu untuk mempertunjukkan proses tertentu. Seperti yang disampaikan oleh Edison bahwa:

Metode demonstrasi merupakan metode mengajar dengan cara instruktur atau tim pendidik menunjukan dan memperlihatkan suatu proses. Metode demonstrasi adalah suatu cara mengajar dengan mempertunjukkan cara kerja suatu benda. Benda tersebut dapat berupa benda sebenarnya atau suatu model. Metode demonstrasi memberi visualisasi yang nyata dan sangat jelas sehingga mudah dimengerti dan dihayati oleh peserta didik. ${ }^{79}$

Hal yang sama juga disampaikan oleh Junaedi mengutip pendapat Ali Mudlofir dan Evi Fatimatur Rusydiyah yang menjelaskan bahwa: metode demonstrasi adalah metode belajar yang dilakukan dengan cara memperagakan barang, kejadian, aturan, dan urutan dalam melakukan suatu kegiatan, baik secara langsung maupun melalui penggunaan media. ${ }^{80}$ Metode demonstrasi adalah cara belajar dilakukan oleh peserta didik dengan cara memperagakan, memperlihatkan atau mempertunjukkan cara kerja, urutan kejadian atau aturan-aturan yang berlaku.

Tujuan penggunaan metode demonstrasi digunakan untuk memperlihatkan sesuatu proses atau cara kerja suatu benda yang berkenaan dengan bahan pelajaran. Dapat juga dikatakan bahwa, demonstrasi merupakan praktik yang diperagakan. Edison menjelaskan ada dua tujuan demonstrasi yaitu: 1). Demonstrasi sebagai proses yang digunakan untuk memahami langkah demi langkah. 2). Demonstrasi bertujuan untuk memperlihatkan hasil atau memperagakan hasil dari suatu proses. ${ }^{81}$ Berdasarkan kutipan di atas dapat dipahami bahwa melalui metode demonstrasi peserta didik dapat memahami langkah-langkah dalam demonstrasi dan juga peserta didik melihat proses bahkan hasil dari pembelajaran yang didemonstrasikan. Dengan kata lain dapat dinyatakan bahwa belajar melalui metode demonstrasi memberikan pengalaman belajar secara langsung kepada peserta didik, sebab melalui metode demonstrasi peserta didik dapat mengalami secara pribadi, dimana peserta didik dapat melihat, mempraktikkan dan merasakan secara langsung. Seperti yang disampaikan oleh Edison bahwa: "melaui metode demonstrasi peserta didik dapat memperoleh pengalaman belajar secara langsung setelah melihat, melakukan dan merasakan sendiri." ${ }^{2}$

Selain memiliki tujuan metode demonstrasi juga memikili manfaar bagi peserta didik dalam proses belajar. Seperti yang dijelaskan oleh Mariyaningsi dan Hidayati menjelaskan beberapa manfaat metode demonstrasi yang bagi peserta didik yaitu:

\footnotetext{
${ }^{77}$ Suyanto dan Asep Jihad, Menjadi Guru Profesional: Strategi Meningkatkan Kualifikasi dan Kualitas Guru di Era Global (Jakarta: Erlangga Group, t.t), 114

${ }^{78}$ Ibid., 114.

${ }^{79}$ F. Thomas Edison, 52 Metode Mengajar: Mengangkat Harkat dan Martabat Pendidik Menjadi Berwibawa dan Terhormat (Bandung: Kalam Hidup, 2017), 68.

${ }^{80}$ Abdul Kadir Sahlan, Mendidik Perspektif Psikologi (Yogyakarta: Deppublish, 2012), 119.

${ }^{81}$ Abdul Kadir Sahlan, Mendidik ..., 119.

${ }^{82}$ F. Thomas Edison, 52 Metode Mengajar:..., 68.
} 
a. Dapat memusatkan perhatian peserta didik

b. Mengarahkan proses belajar pada materi utama

c. Peserta didik memperoleh pengalaman dan kesan belajar yang bermakna

d. Membantu meningkatkan daya pikir peserta didik dalam mengenal, mengingat, berpikir konvergen dan evaluatif.

e. Dapat memberikan ilustrasi dalam menjelaskan informasi serta memberikan kesempatan kepada peserta didik untuk memikirkan mengapa suatu kejadian terjadi, bagaimana hal tersebut terjadi, dan apa yang akan terjadi selanjutnya ${ }^{83}$

3) Belajar melalui Studi Mandiri

Studi mandiri memiliki dua kata, yaitu "studi" dan "mandiri". Studi dapat diartikan sebagai belajar dan mandiri diartikan sebagai kemampuan untuk bertanggung jawab atas proses belajar untuk diri sendiri. Terdapat beberapa definisi tentang belajar mandiri, menurut Little yang dikutip oleh Wicaksono dan Roza dalam buku Teori Pembelajaran Bahasa: Suatu Catatan Singkat yang mendefinisikan kemandirian adalah suatu kapasitas untuk membuat refleksi kritis, membuat keputusan dan menindaklanjuti keputusan itu. ${ }^{84}$ Selanjutnya pendapat Dickinson dalam buku yang sama juga memberikan definisi mengenai kemandirian dalam belajar ialah sebuah situasi yang menuntut peserta didik secara total bertanggung jawab untuk semua keputusan menyangkut proses belajarnya dan melakukan keputusan tersebut. Selain itu, kemandirian belajar merupakan sebuah kesiapan untuk bertanggung jawab atas proses belajar seseorang untuk melayani kebutuhan dan tujuan yang ingin dicapainya. ${ }^{85}$

Dari beberapa pengertian belajar mandiri di atas, dapat disimpulkan bahwa belajar mandiri merupakan kegiatan belajar aktif yang didorong oleh niat atau motif untuk menguasai suatu kompetensi dalam rangka menyelesaikan suatu masalah. Hal tersebut dibangun dengan bekal pengetahuan atau kompetensi yang telah dimiliki.

Pendapat Ellington dan Duncan Harris yang dikutip oleh Gasong bahwa: "Belajar mandiri bermakna suatu sistem pembelajaran yang mengarahkan peserta didik menggunakan sebagian besar waktu belajarnya secara sendirian hanya bertemu dengan pendidik untuk memperoleh pengarahan, bimbingan dan bantuan, serta untuk mengkaji kemajuan." Melalui metode belajar mandiri peserta didik dilatih untuk belajar secara mandiri tidak bergantung kepada pihak lain. Melalui belajar mandiri seorang peserta didik harus mampu berpikir, bersikap dan bertindak secara pribadi. Belajar mandiri yaitu peserta didik dapat mengambil keputusan yang diperlukan untuk memenuhi kebutuhannya. Belajar mandiri berfokus pada pemberian kesempatan dan pengalaman kepada peserta didik agar mampu, percaya diri, dan termotivasi untuk belajar. ${ }^{87}$ Studi mandiri atau belajar secara mandiri akan memupuk kemandirian peserta didik dalam belajar, mengambil keputuan dan menyelesaikan permasalahan.

\footnotetext{
${ }^{83}$ Nining Mariyaningsi dan Mistina Hidayati, Bukan Kelas Biasa: Teori dan Praktik Berbagai Model dan Metode Pembelajaran Menerapkan Inovasi Pembelajaran di Kelas-kelas Inspiratif(Surakarta: CV Kekata Group, 2018), 84.

${ }^{84}$ Andri Wicaksono dan Ahmad Subhan Roza, Teori Pembelajaran Bahasa: Suatu Catatan Singkat (Yogyakarta: Garudhawaca, 2016), 430.

${ }^{85}$ Ibid., 430.

${ }^{86}$ Dina Gasong, Belajar dan Pembelajaran (Yogyakarta: Deepulish, 2018), 38.

${ }^{87}$ Cryril Kesten, Independent Learning (London: Saskatchewan Education, 1987), 3.
} 
4) Belajar melalui Diskusi

Diskusi berasal dari bahasa Latin, yaitu discutio atau discusium yang artinya bertukar pikiran. Diskusi pada dasarnya merupakan suatu bentuk tukar pikiran yang teratur dan terarah, baik dalam kelompok kecil maupun besar, dengan tujuan untuk mendapatkan suatu mengenai suatu pengertian, kesepakatan, dan keputusan bersama mengenai suatu masalah. ${ }^{88}$

Metode diskusi pada dasarnya adalah suatu proses bertukar informasi, pendapat, dan unsur-unsur pengalaman secara teratur dengan maksud untuk mendapatkan pengertian bersama yang lebih jelas dan lebih cermat tentang permasalahan atau topik yang sedang dibahas. Penggunaan metode diskusi kelas bertujuan untuk memberikan kesempatan kepada peserta didik untuk menyatakan pandangannya. Diskusi adalah metode pembelajaran yang menghadapkan peserta didik pada suatu permasalahan. Tujuan utama metode ini adalah untuk memecahkan suatu permasalahan, menjawab pertanyaan, menahan dan pengetahuan peserta didik, serta untuk membuat suatu keputusan. Oleh karena itu, diskusi bukanlah debat yang bersifat adu argumentasi. Diskusi lebih bersifat bertukar pengalaman untuk menentukan keputusan tertentu secara bersama-sama.

Belajar melalui metode diskusi memberikan banyak manfaat bagi peserta didik. Terdapat beberapa pendapat mengenai manfaat metode diskusi. Menurut Wicaksono dan Roza metode diskusi bertujuan untuk: 1) Mendorong peserta didik berpikir kritis. 2) Mendorong peserta didik mengekspresikan pendapatnya secara bebas. 3). Mendorong peserta didik menyumbang buah pikiran untuk memecahkan masalah bersama. 4). Mengambil satu atau beberapa alternatif jawaban untuk memecahkan masalah berdasarkan pertimbangan yang cermat. $^{89}$

Berdasarkan penjelasan di atas dapat disimpulkan beberapa tujuan penggunaan metode diskusi dalam kegiatan belajar yaitu:

a. Melatih peserta didik untuk berpikir secara logis karena dalam proses diskusi ada debat argumen.

b. Meningkatkan kemampuan berpikir peserta didik dalam pemecahan masalah, sebab argumentasi yang dikemukakan akan dinilai oleh anggota orang lain.

c. Melatih peserta didik dalam berbicara, baik secara kebahasaan ataupun non kebahasaan, sebab umpan balik dapat diterima secara langsung.

d. Menolong peserta didik yang pasif untuk terlibat aktif berbicara.

e. Melatih kemampuan peserta didik untuk mempertimbangkan gagasan-gagsan yang berbeda, dan dapat merumuskan persetujuan tanpa emosi untuk menang sendiri.

\section{c) Common Sense Learning (Gaya Belajar dengan Akal Sehat)}

Peserta didik yang memiliki gaya belajar common sense sering disebut sebagai convergers, karena mereka sangat cepat berkumpul untuk membuat keputusan atau untuk mendapatkan satu jawaban yang benar. Mereka lebih suka menerima informasi yang abstrak dan pemrosesan informasi secara aktif.

1) Kata Tanya yang Sering Digunakan adalah "Bagaimana?"

Pertanyaan favorit seseorang yang termasuk dalam kelompok common sense learning adalah bagaimana (how) yang berlanjut dengan how odes this work? Bagaimana cara sesuatu itu bekerja atau dikerjakan? "Bagaimana saya dapat menggunakan cara ini?" Marlene D. Le 2008), 12.

${ }^{88}$ Ismail Kusmayadi, Tink Smarts Bahasa Indodesia (Bandung: Grafindo Media Pratama,

\footnotetext{
${ }^{89}$ Andri Wicaksono dan Ahmad Subhan Roza, 409.
} 
Ferever menjelaskan bahwa: 'Question: How di I use what I know? How does what I've studied actually work today? Bagaimana saya menggunakan apa yang saya ketahui? Bagaimana cara saya belajar hari ini $?^{90}$ Hal yang serupa juga disampaikan oleh Susan B. Bastable tipe peserta didik yang ketiga dalam kuadran ketiga mulai dari otak kiri untuk mengerjakan konsep yang sudah didefinisikan, kemudian beralih ke otak kanan untuk bereksperimen dengan apa yang harus dipelajari. Mereka bertanya, "Bagaimana cara kerjanya? Bagaimana saya dapat?" Ka1 Kata tanya "bagaimana" digunakan untuk menanyakan keadaan atau kejelasan tentang sesuatu hal, cara atau proses pengerjaan sesuatu.

\section{2) Karakteristik Common Sense Learning}

Peserta didik yang memiliki gaya belajar common sense memiliki karakteristik sebagai berikut:

a. Menilai kegunaan suatu moto, produktif, dan efisiensi.

b. Suka mencari tahu bagaimana sesuatu bekerja.

c. Belajar dengan menerapkan dan menguji informasi sesuai dengan model.

d. Mencari dan menemukan tindakan dan pengalaman.

e. Unggul dalam aplikasi praktis, pemikiran strategis, dan cepat membuat keputusan.

f. Bekerja dengan baik sesuai dengan batas waktu, sangat menghargai waktu luang.

g. Ingin melacak informasi langsung pada dasar persolan.

h. Mereka lebih suka bekerja sendirian dan kadang-kadang mengikuti kerja kelompok, terutama aktif dalam membuat keputusan dan diskusi.

i. Lebih suka instruktur yang bertindak sebagai pelatih pembimbing.

j. Dapat bertindak terlalu cepat tanpa daya yang cukup, mempertimbangkan informasi penting sebagai non esensial atau muncul bossy dan impersonal. ${ }^{92}$

Selain beberapa karakteristik yang dapat menggambarkan ciri-ciri seorang pembelajar common sense di atas, berikut ini peneliti memaparkan beberapa cara atau metode belajar yang digunakan, diantaranya yaitu:

\section{1) Belajar melalui Metode Inquiry}

Metode inqury adalah teknik pengajaran yang dilakukan oleh pendidik dengan cara membagi tugas kepada peserta didik untuk meneliti suatu masalah. Inquiry artinya adalah 'penyelidikan'. Jadi, peserta didik yang diberi tugas oleh pendidik untuk mengadakan penyelidikan sendiri agar dapat memecahkan suatu persoalan. ${ }^{93}$ Metode Inquiry melatih dan mengembangkan kemampuan peserta didik dalam dalam menyelidiki dan menyelesaikan permasalahan. Bila dikaitkan dengan kegiatan belajar maka metode inquiry akan melatih setiap peserta didik untuk menyelidiki setiap materi pelajaran ataupun persoalan yang dialami dalam proses belajar dan menyelesaikan masalah tersebut.

Metode inquiry adalah suatu metode pembelajaran yang menumbuhkan hasrat besar untuk ingin tahu. Meningkatkan kemampuan untuk menggunakan atribut, meningkatkan cara belajar sepanjang hayat (learning to learn dan learning throughout life). ${ }^{94}$ Pendapat

${ }^{90}$ Marlene D. Le Ferever, Learning Stayles: Reaching Everyone God Gave You To Teach (Colorado Spring, Co 809 USA: David C. Cook, 2004), 25-26.

${ }^{91}$ Susan B. Bastable, 88 .

${ }^{92}$ Allo Liliwer, 328.

${ }^{93} \mathrm{~F}$. Thomas Edison, 52 Metode Mengajar ..., 72.

${ }^{94}$ Warni Tune Sumar dan Intan Abdul Razak, Strategi Pembelajaran dalam Implementasi Kurikulum Berbasis Soft Skill (Yogyakarta: Deepublish, 2012), 54. 
Roestiyah yang dikutip oleh Santoso dalam bukunya Skema dan Mekanisme Pelatihan: Panduan penyelenggaraan Pelatihan bahwa:

Metode inquiry adalah metode pelatihan dimana trainer membagi tugas meneliti suatu masalah kepada peserta pelatihan. Peserta pelatihan dibagi menjadi beberapa kelompok dan masing-masing kelompok mendapat tugas tertentu yang harus dikerjakan. Kemudian mereka mempelajari, meneliti, dan membahas tugasnya di dalam kelompoknya kemudian membuat laporan yang kemudian didiskusikan secara luas atau melalui pleno sehingga diperoleh kesimpulan terakhir. ${ }^{95}$

Berdasarkan penjelasan di atas metode inqury berarti menekankan kepada aktivitas peserta didik secara maksimal untuk mencari dan menemukan. Artinya metode ini menempatkan peserta didik sebagai subjek belajar. Santoso mengatakan bahwa, metode ini menempatkan pengajar bukan sebai sumber belajar, tetapi sebagai fasilitator dan motivator. ${ }^{96}$ Dalam metode inquiry setiap peserta didik akan berperan sebagai subjek dalam belajar, dalam arti bahwa peserta didiklah yang menjadi pelaku dalam proses belajar. Setiap peserta didik harus berperan secara aktif, sehingga proses belajar dapat terlaksana dengan baik dan dapat mencapai tujuan.

Tujuan dari metode inquiry adalah mengembangkan kemampuan berpikir secara sistematis, logis dan kristis atau mengembangkan kemampuan intelektual sebagai bagian dari proses mental. Dengan demikian, dalam metode inquiry peserta didik tidak hanya dituntut untuk menguasai materi tetapi juga bagaimana menggunakan potensi yang dimilikinya. ${ }^{97}$ Belajar melalui metode inquiry tidak hanya sampai pada tahap mengerti atau memahami materi pelajaran yang telah dipelajari, tetapi mendorong peserta didik untuk dapat memiliki beberapa kemampuan. Sebab metode ini memiliki beberapa tujuan, yaitu sebagai berikut:

a. Mendorong peserta didik untuk berpikir dan atas inisiatifnya sendiri, bersifat objektif, jujur dan terbuka.

b. Merangsang peserta didik untuk berpikir secara sistematis, kritis dan logis.

c. Dapat membentuk dan mengembangkan cell consept pada diri peserta didik.

d. Mendorong peserta didik untuk berpikir intuitif dan merumuskan hipotesisnya sendiri. ${ }^{98}$

2) Belajar melalui metode Pemecahan Masalah (Problem Solving)

Problem solving artinya 'memecahkan atau menyelesaikan masalah." ${ }^{99}$ Metode problem solving merupakan metode yang merangsang peserta didik untuk berpikir dan menggunakan wawasan tanpa melihat kualitas pendapat yang disampaikan. ${ }^{100}$ Hal yang sama juga disampaikan oleh Edison bahwa: "metode problem solving merupakan metode yang bertujuan untuk merangsang peserta didik agar berpikir dan menggunakan wawasannya tanpa melihat kualitas pendapat yang disampaikannya. ${ }^{101}$

Penjelasan di atas memberi pengertian bahwa metode pembelajaran dengan pemecahan masalah atau problem solving adalah penggunaan metode dalam proses pembelajaran dengan jalan melatih peserta didik menghadapi berbagai masalah, baik pribadi

${ }^{95}$ Budi Santoso, Skema dan Mekanisme Pelatihan: Panduan penyelenggaraan Pelatihan (Jakarta: Yayasan Terumbu Karang Indonesia 'TERANGI' , t.t), 39.

${ }^{96}$ Ibid., 39.

${ }^{97}$ Budi Santoso, Skema dan Mekanisme Pelatihan ..., 39.

${ }^{98}$ Ibid., 39.

${ }^{99}$ Ibid., 81.

${ }^{100}$ Budi Santoso, Skema dan Mekanisme Pelatihan ..., 40

${ }^{101}$ F. Thomas Edison, 52 Metode Mengajar..., 80. 
atau kelompok untuk dipecahkan sendiri-sendiri atau bersama-sama. Dalam menggunakan metode ini, pendidik dapat memberikan sebuah permasalahan atau kasus kepada peserta didiknya untuk kemudian dibaca, dipahami dan ditemukan alternatif solusinya. Pendidik dapat menyimak alternatif solusi yang ditawarkan peserta didik, kemudian memberikan petunjuk dan menyimpulkannya. ${ }^{102}$ Lebih lanjut Edison menguraikan secara rinci hal-hal yang harus dilakukan oleh pengajar dalam menggunakan metode problem solving atau pemecahan masalah, yaitu sebagai berikut:

a. Pengajar menyiapkan masalah-masalah yang akan dipecahkan. Masalah-masalah itu jangan terlalu mudah sehingga diremehkan oleh peserta didik, tetapi sebaliknya jangan pula terlalu sukar sehingga dapat tidak terjangkau oleh pemikiran peserta didik.

b. Biasanya, metode problem solving dilakukan secara individual, tidak secara kelompok. hal itu dilakukan karena tujuan dari metode ini adalah untuk merangsang peserta didik agar berpikir kritis dan mengembangkan wawasannya dalam keilmuan tertentu. Namun, bukan hal yang tabu jika metode ini juga dilakukan dalam kelompok kecil antara 3-5 orang.

c. Pengajar memberikan masalah dan meminta semua peserta didik untuk berpikir tentang cara memecahkannya. Biasanya masalah-masalah itu bersifat dilematis atau memerlukan pemikiran yang agak rumit.

d. Pengajar mendorong peserta didik untuk berpikir dan mengemukakan pendapatnya. Jika Susana seolah-olah buntu, pendidik dapat bertanya kepada peserta didik agar satu per satu dan setiap peserta didik yang diberi giliran berpendapat harus mengemukakan pendapatnya walaupun sedikit.

e. Pendidik menciptakan suasana yang kondusif untuk peserta didik agar mereka tidak merasa takut, malu, dan tidak gugup ketika berbicara menyampaikan pendapatnya.

f. Pada akhir pelajaran, pendidik menyimpulkan pendapat para peserta didik dengan mempertimbangkan semua pendapat mereka. Semua pendapat peserta didik itu dihargai oleh pendidik dengan menyebutkan nama mereka yang berpendapat benar atau mendekati benar.

g. Simpulan yang diambil adalah cara memecahkan masalah yang dihadapi. ${ }^{103}$

\section{3) Belajar melalui Metode Permainan Games}

Bermain merupakan proses pembelajaran yang melibatkan pikiran, persepsi, konsep, kemahiran sosial, dan fisik. ${ }^{104}$ Permainan dalam pembelajaran sering disebut dengan belajar berbasis game (game based learning) atau permainan pendidikan (educational game). Istilah ini digunakan untuk membedakan permaianan yang berkaitan dengan olah raga dengan permaianan yang dirancang khusus untuk tujuan pembelajaran. Dengan demikian, permainaan pendidikan adalah strategi pembelajaran yang mengintegrasikan permainan untuk mengembangkan sikap dan keterampilan dalam situasi yang menyenangkan. Misalnya teka-teki silang, permainan kata, matching game, tebak kata dan lain sebagainya. ${ }^{105}$ Menurut Depdiknas yang dikutip oleh Damadi yang menyatakan bahwa, permainan (game) adalah suatu kegiatan yang melibatkan interaksi antar individu atau antar kelompok untuk mencapai tujuan. Sasaran permainan dibatasi berdasarkan pada aturan-aturan yang telah disepapakati

${ }^{102}$ Shoimatul Ula, Revolusi Belajar: Optimal Kecerdasan melalui Pembelajaran Berbasis Kecerdasan Majemuk (Yogyakarta: Ar-Ruzz Media, 2013), 72.

${ }^{103} \mathrm{~F}$. Thomas Edison, 52 Metode Mengajar ..., 81-82.

${ }^{104}$ Darmadi, Asyik Belajar Sambil Bermain...., 30

${ }^{105}$ M. Yaumi, Media \& teknologi Pembelajaran (Jakarta: Prenada Media Group, 2018), 72. 
baik tertulis maupun lisan, dan cara penyajian bahan pelajaran melalui pengalaman atau belajar sambil bermain. ${ }^{106}$

Fungsi permainan (game) adalah untuk meningkatkan motivasi dan mengairahkan rasa ingin tahu. Dalam pembelajaran metode permainan mempunyai tujuan antara lain untuk mengajarkan pengertian (konsep), menanamkan nilai dan memecahkan masalah, disamping itu juga dapat menumbuhkan aspek kognitif, afektif, dan psikomotorik. Permainan bermanfaat untuk mengendorkan saraf-saraf yang kencang, tegang, menghindarkan kebosanan, menghilangkan kelelahan, asalkan semua itu memiliki nilai manfaat bagi peserta didik dan bagi kelangsungan dan kelancaran aktivitas pengajaran. Belajar melalui permainan (game) dapat menciptakan situasi belajar yang menyenangkan, menghindarkan peserta didik dari kejenuhan dan dapat meningkatkan semangat serta gairah dalam belajar.

\section{d) Dynamic Learning (Gaya Belajar Dinamik)}

Peserta didik dynamic learning senang menganalisis hal-hal yang bersifat praktis. Seperti yang dijelaskan oleh Bastable bahwa dynamic learning memulai menganalisis sesuatu dari otak kiri untuk menganalisis kepraktisan dari apa yang telah dipelajari, tetapi kemudian berpindah ke otak kanan untuk menunjukkan keahlian dengan cara menetapkan dan membagi temuan dengan yang lain. ${ }^{107}$ Selain itu peserta didik dynamic learning juga sering sebagai accommodator, karena mahir dan unggul dalam mengakomodasi atau mengadaptasikan pengetahuan dengan situasi baru. Mereka secara aktif menerima informasi konkret kemudian memprosesnya.

Peserta didik dynamic learning merupakan orang yang dinamis. Kata dinamis berasal dari bahasa Yunani yaitu kata dinamika yang berarti dapat, mampu. Kata dinamis memiliki arti kemampuan, kekuatan. ${ }^{108}$ Dalam Kamus Bahasa Indonesia kata dinamis berarti penuh semangat dan tenaga sehingga cepat bergerak dan mudah menyesuaikan diri dengan keadaan dan sebagainya. ${ }^{109}$ Penjelasan yang senada juga disampaikan oleh Bertens bahwa, kata dinamis merupakan kemampuan atau menjalankan kemampuan. ${ }^{110}$ Berdasarkan penjelasan di atas maka dinamis dapat diartikan sebagai kemampuan atau kekuatan yang mendorong seseorang untuk bergerak atau melakukan sesuatu.

\section{1) Kata Tanya yang Digunakan Adalah "Bagaimana Jika?"}

Pertanyaan favorit para peserta didik Dynamic Learning adalah what if atau just if), dilanjutkan dengan "bagaimana jika saya melakukan perubahan ini, saya ingin tahu apa saja yang akan terjadi?" Le Ferever menjelaskan bahwa: 'Question: what can this become? What if I added this- or that - to what I know? Apa ini bisa terjadi? Bagaimana jika saya menambahkan ini atau itu pada pada yang saya ketahui? ${ }^{111}$ Nada yang sama juga dituliskan Bastable dalam bukunya menjelaskan bahwa, dalam proses belajar dengan menggunakan metode ini mereka sering bertanya, "Jika saya mempelajari hal ini, apa yang dapat saya lakukan? atau dapatkah saya menerapkannya? ${ }^{12}$

\footnotetext{
${ }^{106}$ Darmadi, Asyik Belajar Sambil Bermain ..., 30.

${ }^{107}$ Susan B. Bastable, 88.

${ }^{108}$ N. Drijarkara, Filsafat Manusia (Yogyakarta: Kanisius, 1969), 22.

${ }^{109} \mathrm{https}: / / \mathrm{kbbi}$.web.id/dinamis

${ }^{110}$ K. Bertens, Panorama Filsafat Modern (Jakarta: PT. Mizan Publika, 2005), 98.

${ }^{111}$ Marlen e D. Le Ferever, Learning Stayles: Reaching Everyone God Gave You To Teach (Colorado Spring, Co 809 USA: David C. Cook, 2004), 25-26.

${ }^{112}$ Susan B. Bastable, 88 .
} 
2) Karakteristik Pembelajar Dynamic Learning

Peserta didik dynamic learning memiliki karakteristik sebagai berikut:

a. Memberi nilai secara bervariatif kepada sesuatu.

b. Luwes, suka pengalaman baru dan selalu berusaha untuk menemukan sesuatu yang baru.

c. Cepat mengambil risiko terhadap perubahan.

d. Belajar dengan trial and error, suka mencari peluang baru, dan suka mempengaruhi orang lain.

e. Unggul dalam pemecahan masalah secara aktif, mencari kemungkinan-kemungkinan baru, memperkaya apa yang ada dan mempengaruhi orang lain.

f. Suka ditantang dan kinerja yang dalam dalam situasi kritis.

g. Tidak menyukai prosedur dan jadwal yang ketat

h. Menyukai variasi dan pengaturan masalah tidak terstruktur dan openended.

i. Mengandalkan orang lain untuk informasi dalam memecahkan masalah dan bukan pada anlisis teknis mereka sendiri.

j. Bekerja dengan baik dalam kelompok-kelompok dan menikmati diskusi.

k. Mungkin memiliki rencana praktis, dapat dibelakang jadwal, akan terjebak dalam kegiatan sepele, dan muncul ambisius dan manipulatif kadang-kadang. ${ }^{113}$

Selain beberapa karakteristik yang dapat menggambarkan ciri-ciri seorang pembelajar common sense di atas, berikut ini peneliti memaparkan beberapa cara atau metode belajar yang digunakan, di antaranya yaitu:

\section{1) Belajar melalui Metode Discovery}

Metode belajar discovery adalah cara belajar yang didefinisikan sebagai proses pembelajaran yang terjadi apabila pelajaran tidak disajikan secara utuh. Tetapi diharapkan peserta didik mengorganisasi sendiri. Hal ini berlandaskan pada pendapat Bruner bahwa: 'Discovery learning can defined as the learning that takes place when the student is not presented with subject matter in the final form, but rather is required to organize it him self' dasar ini adalah anak yang harus aktif dalam belajar. ${ }^{114}$ Selain itu pendapat ini didukung Budingsih yang di kutip oleh Darmadi bahwa metode belajar discovery adalah memahami konsep, arti, dan hubungan melalui proses intuitif untuk akhirnya sampai kepada suatu kesimpulan. ${ }^{115}$

Penjelasan di atas menjelaskan bahwa metode pembelajaran discovery (penemuan) adalah metode mengajar yang mengatur pengajaran sedemikian rupa sehingga anak memperoleh pengetahuan yang sebelumnya belum diketahuinya itu tidak melalui pemberitahuan, sebagian atau seluruhnya ditemukan sendiri. Belajar melalui metode discovery, diharapkan peserta didik dapat menemukan konsep-konsep dan prinsip-prinsip melalui proses mentalnya sendiri. Dalam menemukan konsep, peserta didik melakukan pengamatan, menggolongan, membuat dugaan, menjelaskan, menarik kesimpulan dan sebagainya untuk menemukan beberapa konsep atau prinsip. Belajar melalui metode discovery peserta didik dapat melakukan pengamatan, menemukan konsep, melakukan klasifikasi atau pengelompokkan dan menarik suatu kesimpulan.

\footnotetext{
${ }^{113}$ Allo Liliwer, 328-329.

${ }^{114}$ Darmadi, Pengembangan Model Metode Pembelajaran dalam Dinamika Belajar Siswa (Yogyakarta: Deepublish, 2017), 107.

${ }^{115}$ Ibid., 107.
} 


\section{2) Belajar melalui Metode Brainstorming}

Metode belajar brainstorming atau sumbang saran merupakan suatu cara mengajar dengan mengutarakan suatu masalah ke depan kelas, kemudian peserta didik menjawab dengan mengemukakan pendapat, jawaban, atau komentar sehingga masalah tersebut dapat ditemukan jawabannya atau cara mengatasinya. ${ }^{116}$ Dalam metode belajar brainstorming atau sumbang saran, setiap peserta didik diharapkan mengemukakan pendapatnya. Untuk itu, pendidik perlu menghargai semua pendapat yang telah disampaikan, apakah itu benar atau salah. Dalam hal itu, pendidik melatih para peserta didik agar berani mengemukakan pendapatnya dan agar percaya diri. ${ }^{117}$ Ketika peserta didik melakukan brainstorming maka tampak sekali mereka dapat mengemukakan variasi alternatif yang berbeda, ini dimungkinkan karena mereka dapat menerima informasi dari pengalaman yang konkret dan dihubungkan dengan yang mereka lihat. ${ }^{118}$ Peserta didik akan terlatih dalam melihat suatu peristiwa atau ide dari perspektif yang berbeda.

Berikut ini kelebihan metode belajar brainstorming atau sumbang saran, yaitu:

a. Dapat menumbuhkan sifat disiplin peserta didik karena peserta didik siap untuk memberikan saran.

b. Dapat menumbuhkan sikap demokratis peserta didik karena setiap saran dihargai.

c. Peserta didik dapat terlibat secara aktif menyatakan pendapatnya.

d. Peserta didik dilatih untuk berpikir cepat dan tersusun secara logis.

e. Peserta didik dirangsang untuk selalu mengeluarkan pendapatnya yang berhubungan dengan masalah yang diberikan.

f. Adanya persaingan yang sehat di antara peserta didik

g. Dapat meningkatkan partisipasi peserta didik dalam proses pembelajaran

h. Peserta didik dapat saling melatih atau mendukung temannya yang kurang aktif. ${ }^{119}$

\section{3) Belajar melalui Metode Studi Kasus}

Peserta didik yang metode belajarnya melalui metode studi kasus adalah peserta didik yang senang belajar dari kasus-kasus atau suatu peristiwa yang yang terjadi. Hal ini dapat dijelaskan dari pengerian metode studi kasus yang disampaikan oleh Edison, bahwa: "Metode studi kasus adalah metode mengajar dengan cara memberikan penjelasan tentang suatu masalah atau suatu kejadian dalam situasi tertentu." ${ }^{20}$ Belajar melalui studi kasus dituntut adanya analisis yang mendalam, agar dapat memahami, memecahkan masalah yang terjadi. Seperti yang juga dijelaskan oleh Edison bahwa: "dalam metode ini sangat dituntut analisis yang mendalam yang ditinjau dari berbagai sudut pandang dan ulasan yang berasal dari para ahli." ${ }^{, 21}$ Belajar melalui metode belajar studi kasus, peserta didik dapat:

a. Peserta didik dapat berpikir secara secara logis dan sistematis dalam menyelesaikan suatu masalah. Mereka dapat menetapkan berbagai alternatif untuk menyelesaikan masalah tertentu. Mereka pun dapat memahami cara penyelesaian masalah yang nyata terjadi dalam kehidupan sehari-hari.

b. Peserta didik dapat mempererat relasi antar peserta didik karena saling berinteraksi dalam diskusi untuk memecahkan masalah persoalan atau kasus yang sedang dihadapi.

c. Dapat memperkuat rasa percaya diri para peserta didik karena pendapat mereka dihargai dan dapat diterima oleh teman-temannya. ${ }^{122}$

\footnotetext{
${ }^{116} \mathrm{~F}$. Thomas Edison, 52 Metode Mengajar..., 53.

${ }^{117}$ Ibid., 53.

${ }^{118}$ Alo Liliwer, 237.

${ }^{119}$ F. Thomas Edison, 52 Metode Mengajar ..., 53.

${ }^{120}$ Ibid., 142.

${ }^{121}$ Ibid., 142.

${ }^{122}$ Ibid., 143-144.
} 
4) Belajar melalui Metode Eksperimen (trial and eror)

Metode eksperimen adalah suatu metode penyajian pembelajaran di mana peserta didik melakukan eksperimen dengan mengalami dan membuktikan sendiri sesuatu yang dipelajarinya. ${ }^{123}$ Dalam proses pembelajaran peserta didik diberi kesempatan untuk mengalami atau melakukan sendiri; mengikuti suatu proses; mengamati suatu objek, keadaan, atau proses tersebut. Peserta didik mendapat pengalaman belajar dalam mengatasi masalah dengan pendekatan problem solving melalui eksperimen. ${ }^{124}$ Hal yang sama juga disampaikan oleh Ula bahwa, melalui metode ini peserta didik diberi kesempatan untuk mengalami sendiri atau melakukan sendiri, mengikuti proses, mengamati suatu objek, menganalisis, membuktikan dan menarik kesimpulan sendiri tentang suatu objek, keadaan atau proses tertentu. ${ }^{125}$ Tujuan metode belajar eksperimen adalah meningkatkan kemampuan peserta didik untuk dapat belajar mandiri dan memecahkan masalah. ${ }^{126}$ Melalui metode eksperimen dapat meningkatkan kemandirian dan kemampuan peserta didik dalam pemecahan masalah.

\section{HASIL PENELITIAN}

Hasil penelitian di lapangan dapat dilihat pada hasil uji hipotesis dilakukan. Uji hipotesis dilakukan melalui beberapa langkah, dan hasilnya dapat dilihat sebagai berikut:

$\mu_{0}=$ (Nilai Hipotesis) $x$ (Mean Skor Ideal)

Keterangan:

Nilai hipotesis $\quad=50 \%$

Mean skor ideal $=\{($ skor tertinggi tiap item $) \times($ jumlah item variable $\mathrm{X})$

$\mathrm{x}$ (jumlah responden) $\}: \mathrm{N}$

$=(5 \times 56 \times 41): 41$

$=21480: 41$

$=280$

$\mu_{0}=(50 \%) \times 280$

$=140$

Jadi, nilai yang dihipotesis $\left(\mu_{0}\right)$ dari variabel implementasi gaya belajar (4MAT System) oleh peserta didik program studi Pendidikan Agama Kristen di Sekolah Tinggi Teologi Kristus Alfa Omega Semarang adalah 50\% atau sama dengan 140. Selanjutnya dilakukan perhitungan nilai rata-rata empiris (mean skor empiris), adapun hasilnya seperti di bawah ini:

Mean skor empiris $\quad=($ Total Skor Empiris $):($ jumlah responden $)$

$$
=8860: 41
$$$$
=216,097
$$

Berdasarkan perbandingan nilai $\mu_{0}$ adalah $50 \%$ atau sama dengan 140 , sedangkan mean skor empiris adalah 216,097. Dengan demikian diketahui bahwa, nilai hipotesis $\left(\mu_{0}\right) 50 \%$ atau sama dengan 140, tidak sama dengan nilai skor empiris yaitu 216,097. Dengan arti lain nilai skor empiris terbukti lebih besar dari nilai hipotesis $\left(\mu_{0}\right)$. Jadi, hipotesis yang berbunyi bahwa:

\footnotetext{
${ }^{123}$ Nursalam dan Ferry Efendi, Pendidikan dalam Keperawatan (t.k: Salemba Medika, tt), 114.

${ }^{124}$ Ibid., 114.

${ }^{125}$ Shoimatul Ula, 73.

${ }^{126}$ Nursalam dan Ferry Efendi, 114.
} 
$\mathrm{H}_{0}$ : diduga implementasi gaya belajar (4MAT System) oleh peserta didik program studi Pendidikan Agama Kristen di Sekolah Tinggi Teologi Kristus Alfa Omega Semarang adalah sedang atau $\leq 50 \%$.

$\mathrm{H}_{\mathrm{a}}$ : diduga implementasi gaya belajar (4MAT System) oleh peserta didik program studi Pendidikan Agama Kristen di Sekolah Tinggi Teologi Kristus Alfa Omega Semarang adalah bukan dalam kategori sedang atau $>50 \%$.

Maka $\mathrm{H}_{0}$ yang berbunyi diduga implementasi gaya belajar (4MAT System) oleh peserta didik program studi Pendidikan Agama Kristen di Sekolah Tinggi Teologi Kristus Alfa Omega Semarang adalah sedang atau $\leq 50 \%$ ditolak dan $\mathrm{H}_{\mathrm{a}}$ yang berbunyi diduga implementasi gaya belajar (4MAT System) oleh peserta didik program studi Pendidikan Agama Kristen di Sekolah Tinggi Teologi Kristus Alfa Omega Semarang adalah bukan dalam kategori sedang atau $>50 \%$ diterima.

Selanjutnya untuk mengetahui nilai implementasi gaya belajar (4MAT System) oleh peserta didik program studi Pendidikan Agama Kristen di Sekolah Tinggi Teologi Kristus Alfa Omega Semarang dapat dilakukan dengan cara berikut:

Harga \% Variabel $X=\frac{\Sigma \text { Skor Empiris }}{\Sigma \text { Skor Ideal }} \times 100 \%$

Keterangan:

Total skor empiris

$=$ Skor total data variabel $\mathrm{X}=8860$

Total skor ideal

$=($ skor tertinggi tiap item $) \mathrm{x}$ (jumlah item variable $\mathrm{X})$

$\mathrm{x}$ (jumlah responden)

$=5 \times 56 \times 41$

$=11480$

Harga \% Variabel X $\quad=(8860: 11480) \times 100 \%$

$=77.177 \%$

Berdasarkan perhitungan di atas diperoleh nilai persentase implementasi gaya belajar (4MAT System) oleh peserta didik program studi Pendidikan Agama Kristen di Sekolah Tinggi Teologi Kristus Alfa Omega Semarang selanjutnya nilai ini akan diinterpretasi dengan tabel interpretasi hipotesis di bawah ini:

Tabel 4.25

Pedoman untuk Interpretasi makna Persentase Deskriptif ${ }^{127}$

\begin{tabular}{|c|l|}
\hline Prosentase & \multicolumn{1}{|c|}{ Makna } \\
\hline $0-20$ & Sangat Rendah \\
\hline $21-40$ & Rendah \\
\hline $41-60$ & Sedang \\
\hline $61-80$ & Tinggi \\
\hline $81-100$ & Sangat Tinggi \\
\hline
\end{tabular}

Berdasarkan tabel di atas maka nilai implementasi gaya belajar (4MAT System) oleh peserta didik program studi Pendidikan Agama Kristen di Sekolah Tinggi Teologi Kristus Alfa

\footnotetext{
${ }^{127}$ Gideon Joshua, Penelitian Terhadap Hubungan Persepsi Gembala Sidang tentang Pemimipin Hamba dengan Keberhasilan Memimpin Gereja Lokal (Semarang: 2009), 113.
} 
Omega Semarang dengan nilai $77,177 \%$ yang berada pada persentase tinggi yaitu antara (61$80)$.

\section{E. KESIMPULAN}

Berdasarkan pembahasan maka dapat ditarik kesimpulan bahwa gaya belajar 4MAT System merupakan gaya belajar yang dikembangkan oleh McCarthy pada tahun 1980, yang terdiri atas empat indikator yaitu: imaginative learning, analytic learning, common sense learning dan dynamic learning. Berdasarkan penelitian maka diperoleh bahwa tingkat implementasi gaya belajar 4MAT System oleh peserta didik program studi Pendidikan Agama Kristen di Sekolah Tinggi Teologi Kristus Alfa Omega Semarang adalah sebesar 77,177\% yang berada pada kategori tinggi yaitu (61-80).

\section{DAFTAR PUSTAKA}

Alo Liliwer. Komunikasi Serba Ada Serba Makna. Jakarta: Kencana Media Group. 2011.

Amir Faisal dan Zulfanah. Menyiapkan Anak Jadi Juara. Jakarta: PT Media Komputindo. 2008. Andreas B. Subagyo. Pengantar Riset Kuantitatif \& Kualitatif. Bandung: Kalam Hidup. 2004.

Andy Hargreaves, Lorna Earl, dan Jim Ryan. Schooling for Change: Reinventing Edication for Early Adolescents. London: Falmer Press. 1996.

Azizi Yahaya, Asmah Suboh, Zurihanmi Zakariya dan Fauziah Yahya. Aplikasi Kognitif dalam Pendidikan. Kuala Lumpur: Zafar SDn Bhd, 2005.

Barbara Prashing. The Power Learning Styles: Memacu Anak Melejitkan Prestasi dengan Menggali Gaya Belajarnya. Bandung: Kaifa. 2017.

Bobbi DePorter dan Mike Hernack. Quantum Learning Membiasakan Belajar Nyaman dan Menyenangkan. Bandung: Kaifa. 2007.

Cheri Fuller. Maksimalkan Potensi Belajar Anak: Bagaimana Melengkapi Anak Agar Sukses di Sekolah dan dalam Kehidupan. Bandung: Kalam Hidup. 2007.

Darmadi. Pengembangan Model dan Metode Pembelajaran dalam Dinamika Belajar Siswa. Yogyakarta: Deepublish. 2017.

Eni Rombe. Belajar Statistika dengan Mudah: dilengkapi dengan Konsep \& Aplikasi SPSS 17.0. Semarang: KAO PRESS. 2016.

Frederik Buechner. The Son of Laugther. San Francisco: Hangger. 1993.

H. Baharuddin dan Esa Nur Wahyuni. Teori Belajar dan Pembelajaran, Cet.V. Jogjakarta: ArRuzz Media: 2010.

Hamzah B. Uno, Orientasi dalam Psikologi Pembelajaran. Jakarta: PT Bumi Aksara, 2010.

M. Irham dan Novan Ardy Wijani. Psikologi Pendidikan: Teori dan Aplikasi dalam Pembelajaran. Yogyakarta: Ar_Ruzz Media. 2013.

Makmun Khairani. Psikologi Belajar. Yogyakarta: Aswaja Pressindo. 2013.

Marlene D. Le Ferever. Learning Stayles: Reaching Everyone God Gave You To Teach. Colorado Spring, Co 809 USA: David C. Cook. 2004.

Marshall Carol dan Kaye Jhons. Suscces Strategies for At-Risk Students: Center for Succes in Learning Manual. Dallas: Center for Success in Learning. 1992.

Mike Robbins. Focus on the Good Stuff: Mukjizat Bersyukur dan Bermental Positif. Jakarta: PT. Serambi Ilmu. 2007.

Moh. Nazir. Metode Penelitian. Jakarta: Ghalia Indonesia. 1988.

Sasmoko. Metodologi. Jakarta: Perpustakaan Nasional. 2006.

Susan B. Bastable. Perawat sebagai Pendidik. t.k: EGC. 1995..

Toto Syatori Nasehudin dan Nanang Gozali. Metode Penelitian Kuantitatif. Bandung: CV. Pustaka Setia. 2012. 